\title{
Predictors of Human Right Awareness
}

\author{
Dr.D.Ponmozhi, \\ Principal, O.P.R. Memorial College of Education, Vadalur, Tamilnadu, India.
}

\begin{abstract}
The present study is an attempt to find predictors of Human Rights Awareness among D.T.Ed., students of Cuddalore District. 100 samples were taken for the assessment about the human right awareness. Regression analysis was used to analyses the data with the help of IBM SPSS19.The result showed that Parental Occupation alone acted as predictor among personal variables. Among the sub samples International rights awareness is not contributing to the total Human Rights Awareness but Civil Right are the strongest contributor of Human Rights Awareness and Political Rights and Legal Rights successive contributor of Human Rights Awareness of the teacher trainees.
\end{abstract}

Keywords: Civil Rights, Cultural Rights, Educational Rights, Legal Rights, Political Rights, Social Rights and International Rights, Locality, Parental income, Parental Occupation.

\section{INTRODUCTION}

Human rights awareness is the individual awareness about the rights that are fundamental for the human life. The rights included in this group are also very important for the prospective students. These includes right to work, right to have a good standard of living, right to rest and leisure, right to education, and right for equal pay for equal work. The future teachers must have knowledge about their rights and privileges to lead their professional life successfully.

\section{NEED OF THE STUDY}

Human rights awareness of the teacher trainees will help to understand the rights of their future students. They can help their students to fulfill their basic and education rights through guidance. Innocence and ignorance can be removed only through education alone. The future teachers must aware of their own and others rights. So the researcher wants to study the level of awareness about the human rights among the teacher trainees.

\section{Research Objectives of the study}

1. To find the predictor of Human Rights Awareness of the teacher trainees.

2. To find the contributors of Human Rights Awareness of the teacher trainees.

\section{Hypotheses of the study}

1. There is no significant predictor of Human Rights Awareness of the teacher trainees.

2. There are no significant contributors of Human Rights Awareness of the teacher trainees.

\section{MATERIALS AND METHODS}

With the help of random sampling technique 100 student teachers from three teacher training institutes were selected as samples for the study. Two self financing and one government Teacher training institutes were randomly chosen .Human Rights Awareness Questionnaire constructed and standardized by the Kirti Matliwala (2014) has been utilized to collect the data from the sample. The scale contains 30 items in eight sub scale. Civil Rights, Cultural Rights, Economic Rights, Educational Rights, Legal Rights, Social Rights, Political Rights and International Rights constitute the subscale.

\section{IV.} ANALYSIS AND INTERPRETATION

he researcher used regression analysis to find the predictor among personal variables such as gender, locality, type of institution, parental income, age and parental occupation. Civil Rights, Cultural Rights, Economic Rights, Educational Rights, Legal Rights, Social Rights, Political Rights and International Rights (subscale) were use to fond contributor of Human Rights Awareness through IBM SPSS Amos 19. 


\begin{tabular}{|c|c|c|c|c|c|c|}
\hline \multicolumn{7}{|c|}{$\begin{array}{l}\text { Table-1 STEPWISE REGRESSION BETWEEN HUMAN RIGHTS AWARENESS TOTAL } \\
\text { SCORE AND PERSONAL VARIABLES }\end{array}$} \\
\hline & b & SE-b & beta & Pearson $r$ & $\mathbf{S r}^{2}$ & $\begin{array}{l}\text { Structural } \\
\text { coefficient }\end{array}$ \\
\hline (Constant) & 20.182 & 1.279 & & & & \\
\hline Parental occupation* & 2.418 & .786 & $\begin{array}{r}.29 \\
7\end{array}$ & .297 & 0.088 & 1 \\
\hline
\end{tabular}

Table-1 shows gender, locality, type of institution, parental income, age and parental occupation was used in a stepwise multiple regression analysis to predict Human rights awareness. The prediction model contained one of the six predictors and was reached in one step with five variables removed. The model was statistically significant, $F(\mathbf{1 , 9 8})=9.47, p<.001$, and accounted for approximately $8 \%$ of the variance of Human rights awareness $\left(\mathrm{R}^{2}=0.088\right.$, Adjusted $\left.\mathrm{R}^{2}=0.079\right)$. Human rights awareness is primarily predicted by Parental occupation alone. The raw and standardized regression coefficient of predictors together with their correlation with Human rights awareness their squared semi-partial correlations and their structure coefficients are shown in table-1. The Parental occupation received the strongest weight in model. The unique variance explained by each of the variables indexed by the squared semi-partial correlation was relatively low: Parental occupation uniquely accounted for approximately $\mathbf{3 \%}$ of the Human rights awareness. Inspection of the structure coefficient suggests that Parental occupation was strong indicators of Human rights awareness

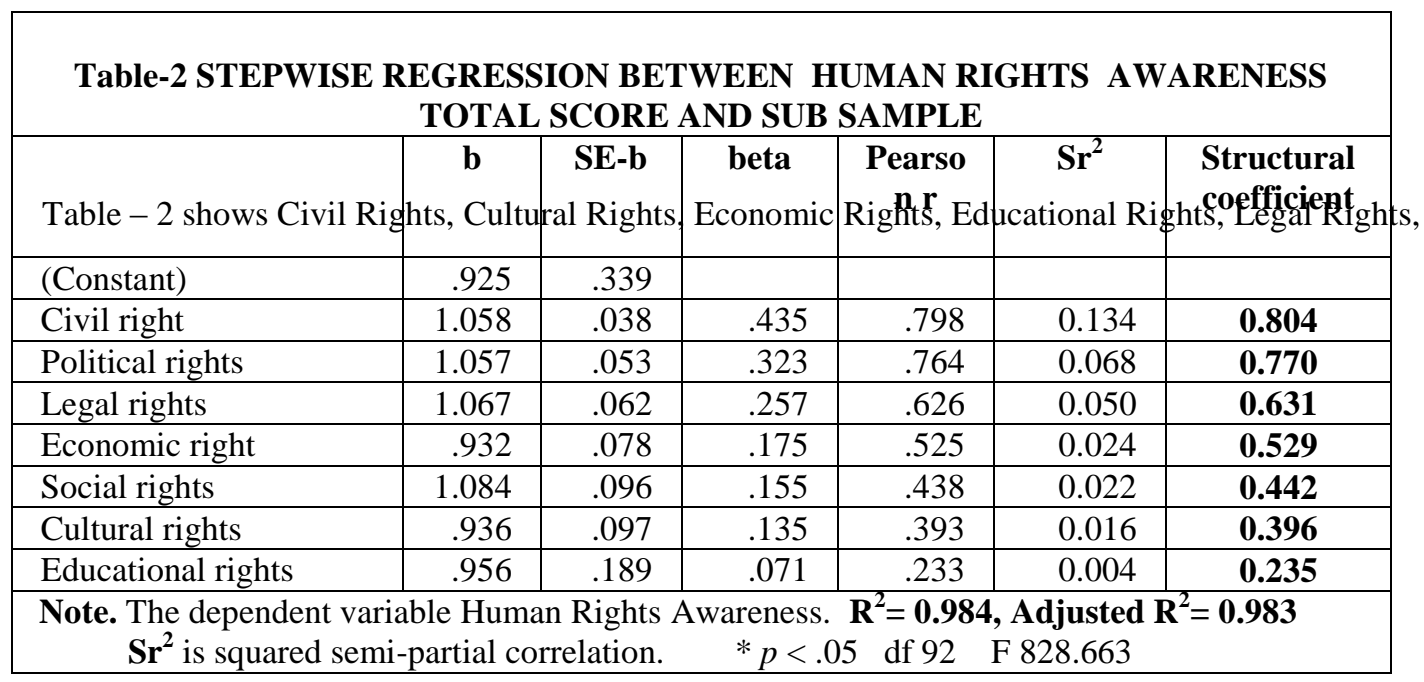

The prediction model contained seven of the eight predictors and was reached in seven steps with one variable removed. The model was statistically significant, $F(7,92)=828.663, p<.001$, and accounted for approximately $\mathbf{9 8 \%}$ of the variance of Human Rights Awareness $\left(\mathrm{R}^{2}=0.984\right.$, Adjusted $\left.\mathrm{R}^{2}=0.983\right)$. Human Rights Awareness is primarily predicted by the higher levels of Civil right, Political rights, Legal rights, Economic right and to the lesser extent by Social rights, Cultural rights and Educational rights. The raw and standardized regression coefficient of predictors together with their correlation with Human rights awareness, their squared semi-partial correlations, and their structure coefficients are shown in table-2.The Civil rights received the strongest weight in model followed by Political rights, Legal rights, Economic right, Social rights, Cultural rights and Educational rights. Educational rights received the lowest weight of the seven weights. With the sizeable correlations between the predictors, the unique variance explained by each of the variables indexed by the squared semi-partial correlation was relatively low: Civil rights, Political rights, Legal rights, Economic right, Social rights, Cultural rights and Educational rights uniquely accounted for approximately $13 \%, 6 \%, 5 \%$, $2 \%, 2 \%, 1 \%$, and $1 \%$ of Human Rights Awareness. Inspection of the structure coefficient suggests that, the 
Civil rights, Political rights and Legal rights were relatively strong indicators of Human rights Awareness, and Cultural rights and Educational rights moderate indicator of Human rights Awareness.

\section{CONCLUSION:}

Parental occupation helps the student teachers to gain knowledge about Human Rights Awareness. Necessary measures should be taken to inculcate Human Rights Awareness among the student teachers to reach all sections of the student teachers. They are very poor in Educational rights and cultural rights. The curriculum should be updated and incorporated with Human Rights Awareness. Many seminars and workshops should be arranged related to Educational rights of the teachers and students.

\section{REFERENCES}

[1] Afroz Alam \& Abdul Wahab, (2015).A Study Of Human Rights Awareness Among Pre-Service Teacher Trainees Of Hyderabad, People's Dialogue on Education, 7(1).

[2] Agharuwhe, A. (2013), Students' and Human Rights Awareness in Secondary Schools' Environment in Delta State, Jep/ Ejournal of Eduction policy estabilished 2000.

[3] Ananthapriya, (2014). Compare the awareness about Human rights of mentally ill among the Male and Female caregivers of patients diagnosed with psychiatric disorders, IOSR Journal of Nursing and Health Science,3(4).

[4] Ashraf.S, (2013). A Study of Human Rights Awareness among Prospective teachers, International Journal of scientific research,2(7).

[5] Bharathi.R \& Sivarathanam.M, (2013). A study of High School Students Attitude Towards Child Rights, Indian Journal of Research in Education and Extension, 4(1).

[6] Jaskiran Kaur Dayal \& Sukhwant Kaur (2015). A Comparative study on Human Rights Awareness Among Teachers working in P.s.e.b. and C.b.s.e. Affiliated Schools, Indian journal of Research, 4(4).

[7] Kaler. S, (2015). Human Rights Awareness in India, Indian Journal of Research,4 (10).

[8] Kamau, I.N. (2013).Influence Of Child's Rights Awareness On Students' Performance In Gatundu Northdistrict, Kiambu County, Kenya

[9] Padmavathy \& Pratima Pallai, (2015). Human Rights Awareness of University Students: An Investigation, International Journal of Humanities and Social Science Invention,4(4).

[10] Pandey (2015). Human Rights Awareness Of Teachers And Teacher Educators In India, Educational Herald.

[11] Poonam Devi (2013). A Study Of Awareness Among Rural Women About Their Rights, Asian Journal of Educational Research \& Technology, 3(2).

[12] Prosper Mangamu (2013), An Assessment of Child Rights Awareness among Basic College Children: A case study of selected basic college pupils in Lusaka urban, didertation for master of development studies, university of Zambia.

[13] Rajesh K.S., (2014). Adolescents' Attitude Towards Human Rights In Relation To Their Personality Variables, Edutracks, 14(4).

[14] Sangeeta K Barwal, (2014). Human Rights Awareness Among Tribal And Non-Tribalsenior Secondary School Students, Conflux Journal of Education, 1(12).

[15] Sathiyaraj.A \&Jayaraman.K, (2013). A Study on Child Rights Awareness among the Primary School Teachers in Tiruchirappalli District of Tamilnadu, International Journal of Scientific and Research Publications, 3(6).

[16] Sharma(2015). Human Rights and Values among Children:The Role of Education, Recent Researches in Education and Psychology, 5

[17] Shoejee Singh \& Harjinder Singh,(2015). Human Rights Awareness Among B.Ed. Students, International Journal of Education, 4.

[18] Suman Kumari Katoch (2014). A Handbook of Human Rights. Creative Learning Series, NBI, New Delhi.

[19] Vimalkumar,P., Pakkirisamy,M.,\& Sivakumar,P.(2014). A Study On The Awareness Of Human Rights Among B.Ed Student Teachers, International Journal of Current Research, 6(1). 